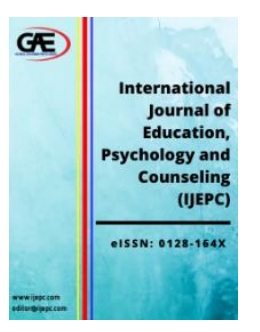

\author{
International Journal of Education, \\ Psychology and Counselling (IJEPC) \\ Journal Website: http://ijepc.com/ \\ eISSN: 0128-164X
}

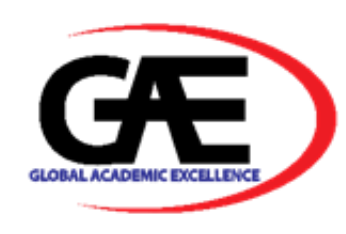

\title{
EXPLORING GIFTEDNESS: TRAITS OF COGNITIVE AND PRACTICAL SKILLS OF A GIFTED CHILD
}

\author{
Md Jais Ismail ${ }^{1 *}$, Azu Farhana Anuar ${ }^{2}$, Rorlinda Yusuf ${ }^{3}$ \\ $1 \quad$ Pusat GENIUS@ pintar Negara, Universiti Kebangsaan Malaysia (UKM), Malaysia \\ Email: md_jais@ukm.edu.my \\ 2 Student Development, General Studies Unit, Universiti Kuala Lumpur Malaysian Institute of Chemical and Bio- \\ Engineering Technology(UniKL MICET), Malaysia \\ Email: azufarhana@unikl.edu.my \\ $3 \quad$ Pusat GENIUS@pintar Negara, Universiti Kebangsaan Malaysia (UKM), Malaysia \\ Email: rorlinda@ukm.edu.my \\ Corresponding Author
}

\section{Article Info:}

Article history:

Received date: 13.01 .2020

Revised date: 03.03.2020

Accepted date: 04.03.2020

Published date: 15.03 .2020

\section{To cite this document:}

Ismail, M. J., Anuar, A. F., \& Yusuf, R. (2020). Exploring Giftedness: Traits of Cognitive and Practical Skills of a Gifted Child. International Journal of Education, Psychology and Counseling, 5 (34), 189-196.

DOI: $10.35631 /$ IJEPC.5340015.

\begin{abstract}
:
Previous studies reveal that there is at least 1 gifted child in 10,000 children. Managing these gifted children at home and schools is in fact a demanding task. Parents and teachers need to understand gifted children's traits in order to cater to their learning needs. This study aims to explore the traits of the cognitive and practical skills of a gifted child through a case study. The respondent is a male child of Pusat GENIUS@pintar Negara, Malaysia, aged 13 years old who has passed the 'gifted tests' which are UKM1, UKM2, and UKM3. Data were collected through in-depth interviews, document analysis, and observations. The result shows that the gifted child possesses high ability in terms of cognitive and practical skills compared to his peers who are at the same age. In terms of cognitive skill, he could answer all questions correctly in a quiz conducted and obtained the highest marks in every examination including intelligence tests namely gifted tests. Whilst, for the practical skill he could master playing violin in a very short period of time even though he had never played one before. Additionally, for both skills, he has won a lot of gold medals at the international level. Thus, the researcher suggests a more comprehensive and acceleration learning should be adapted and allowed the gifted child to tailor his cognitive and emotional needs.
\end{abstract}

Keywords:

Giftedness, Gifted, Children, Traits, Cognitive 


\section{Introduction}

The existence of gifted individuals is valuable asset for a country. There is at least 1 gifted child in 10,000 children (Noriah, 2019; Diezman, 2002). Experts have defined gifted in various views. Gagne (2015) and Renzulli (2002) define gifted as those who possess high cognitive level compared to their peers. Mayer and Salovey (1997) relate gifted with high emotional management. Zohar and Marshall (2012) focus on spriritual gifted. Gardner (2000) has categorised gifted into seven fields as multiple intelligence. Studies show cognitive gifted is related with emotional and spiritual (Noriah, 2005; Goleman, 2000). Although experts agree that giftedness is inherited and influenced from environment, gifted traits are the combination of some factors in order to form success. Terman and Merrill (1960) state cognitive gifted solely cannot determine success. It should hence be integrated with resilience, motivation and clear life direction. Gardner (2000), through his own opinion, narrows the idea that intelligence should be supported by extraneous elements such as body kinesthetics, logics, interpersonal, intrapersonal, and music.

Gifted children are facing psycho emotional problem and stress in getting biological matured. The instability of cognitive and emotion domain has caused confusion among gifted children. This is because these gifted children can think beyond their chorological age while their emotion is not at par as the actual age. This asynchronous development stimulates psychological issues such as perfectionism, anti-social, anxiety, and depression (Noriah \& Abu Yazid, 2014). This issue has become barriers for children studying at school and mingling with others. Teachers and parents should realize the children's needs by identifying traits of giftedness among the children. Intervention such as specific learning for gifted children should be formed immediately to elevate the gifted children's cognitive and practical abilities to a maximum level.

Most of gifted children show obvious intelligence traits by having excellent achievement compared to their peers at school. Nonetheless, gifted children exit across both academic and non-academic domains (Worrell, Subotnik, Olszewski-Kubilius, \& Dixson, 2019). Music is one of the lessons that can strengthen the children's talents and develop their creativeness. Specific music lessons and activities may drift the gifted children manage their emotions effectively and enhance cognitive skills (Md Jais, Rorlinda, \& Loo, 2018; Da Costa \& Lubart, 2016). Gifted character can be nurtured through personality. Kwaśniewska, Gralewski, Witkowska, Kostrzewska, and Lebuda (2018) found that mother's personality affects the children behavior, creativity, and thinking behavior in doing and solving things.

Traits for gifted children can be divided into several categories. Brainbridge (2019) categorised giftedness into cognitive, social and emotional. Gifted children like to learn new things especially involving intellectual activities. To determine gifted traits, researcher referred to Table 1 that consists of material from the National Research Center on the Gifted and Talented by Mary Ruth Coleman, Ph.D., University of North Carolina.

Table 1: 12 Traits of Giftedness

(Adapted from https://bit.ly/2oXc5fK)

\begin{tabular}{|c|c|c|}
\hline Trait Domains & General Description & Behavior \\
\hline $\begin{array}{l}\text { Motivation } \\
\text { Evidence of desire to } \\
\text { learn. }\end{array}$ & $\begin{array}{l}\text { Internal determination or } \\
\text { encouragement that initiates, } \\
\text { directs, or remain individual or } \\
\text { group behavior in order to fulfill a }\end{array}$ & $\begin{array}{l}\text { Demonstrates perseverance in } \\
\text { completing self-selected tasks } \\
\text { (may be culturally influenced); } \\
\text { evident in school or non- school }\end{array}$ \\
\hline
\end{tabular}




\begin{tabular}{|c|c|c|}
\hline & need or achieve goal. & $\begin{array}{l}\text { activities. Enthusiastic learner; has } \\
\text { aspirations to be somebody, to prove } \\
\text { something. }\end{array}$ \\
\hline $\begin{array}{l}\text { Interests } \\
\text { Intense, } \\
\text { sometimes rare, } \\
\text { interests }\end{array}$ & $\begin{array}{l}\text { Activities, avocations, and } \\
\text { objects that have special value or } \\
\text { significance and are given } \\
\text { special attention. }\end{array}$ & $\begin{array}{l}\text { Rare or advanced interests, } \\
\text { topic, or activity; self-starter; } \\
\text { pursues and activity } \\
\text { continuously beyond the peers } \\
\text { group. }\end{array}$ \\
\hline $\begin{array}{l}\text { Communication } \\
\text { Skills } \\
\text { Highly } \quad \text { expressive } \\
\text { with r words, } \\
\text { numbers, } \quad \text { or } \\
\text { symbols }\end{array}$ & $\begin{array}{l}\text { Response and reaction of } \\
\text { signals or meanings through a } \\
\text { system of signs (encryptions, } \\
\text { gestures, language, and } \\
\text { numbers). }\end{array}$ & $\begin{array}{l}\text { Unusual ability to communicate } \\
\text { (verbally, nonverbally, physically, } \\
\text { imaginatively, } \\
\text { symbolically); uses particularly } \\
\text { apt examples, illustrations, or } \\
\text { explanations. }\end{array}$ \\
\hline $\begin{array}{l}\text { Problem-Solving } \\
\text { Ability } \\
\text { Effective, often } \\
\text { inventive, } \\
\text { strategies for } \\
\text { identifying and } \\
\text { solving problems. } \\
\end{array}$ & $\begin{array}{l}\text { Process of determining a correct } \\
\text { sequence of alternatives leading to } \\
\text { a wanted goal or to successful } \\
\text { completion of a performance task. }\end{array}$ & $\begin{array}{l}\text { Rare ability to develop or adopt a } \\
\text { systematic strategy to solve } \\
\text { problems and to change the } \\
\text { strategy if it is not working; creates } \\
\text { new } \\
\text { Designs to be as inventor. }\end{array}$ \\
\hline $\begin{array}{l}\text { Memory } \\
\text { Large storehouse of } \\
\text { information on } \\
\text { school or non-school } \\
\text { themes. }\end{array}$ & $\begin{array}{l}\text { Extraordinary ability to } \\
\text { recall and retrieve } \\
\text { information. }\end{array}$ & $\begin{array}{l}\text { Already knows; needs only } 1-2 \\
\text { repetitions for mastery; has a means } \\
\text { of information about school and } \\
\text { non-school topics; pays attention to } \\
\text { details; improvise information. }\end{array}$ \\
\hline $\begin{array}{l}\text { Inquiry/Curi } \\
\text { osity } \\
\text { Questions, } \\
\text { experiments, } \\
\text { discovers. }\end{array}$ & $\begin{array}{l}\text { Method or procedure of } \\
\text { seeking } \\
\text { understanding or information. }\end{array}$ & $\begin{array}{l}\text { Asks unusual questions for age; } \\
\text { plays around with ideas; extensive } \\
\text { probing behaviors directed toward } \\
\text { producing information about } \\
\text { materials, devices, or situations. }\end{array}$ \\
\hline $\begin{array}{l}\text { Insight } \\
\text { Quickly grasps new } \\
\text { concepts; } \\
\text { understands } \\
\text { connections; senses } \\
\text { deeper meanings }\end{array}$ & $\begin{array}{l}\text { Sudden discovery of correct } \\
\text { solution following attempts based } \\
\text { primarily on trial and error; } \\
\text { putting dissimilar elements } \\
\text { together in unexpected ways. }\end{array}$ & $\begin{array}{l}\text { Special ability to draw inferences; } \\
\text { appears to be a good guesser; is } \\
\text { keenly observant; heightened } \\
\text { capacity for seeing unusual and } \\
\text { diverse relationships, integration } \\
\text { of ideas and } \\
\text { disciplines. }\end{array}$ \\
\hline $\begin{array}{l}\text { Reasoning } \\
\text { Logical approaches } \\
\text { to finding out } \\
\text { solutions. }\end{array}$ & $\begin{array}{l}\text { Highly aware, directed, } \\
\text { controlled, active, intentional } \\
\text { forward-thinking, and goal- } \\
\text { oriented thought. }\end{array}$ & $\begin{array}{l}\text { Ability to generalize and use } \\
\text { images and analogies; can think } \\
\text { things through in a logical manner; } \\
\text { critical thinker; ability to think }\end{array}$ \\
\hline
\end{tabular}




\begin{tabular}{|c|c|c|}
\hline & & $\begin{array}{l}\text { things through and come up with } \\
\text { a reasonable answer. }\end{array}$ \\
\hline $\begin{array}{l}\text { Imagination/Cre } \\
\text { ativity Produces } \\
\text { many ideas; highly } \\
\text { original }\end{array}$ & $\begin{array}{l}\text { Process of forming mental images } \\
\text { of objects; qualities, situations, or } \\
\text { relationships which aren't } \\
\text { immediately outward to the } \\
\text { senses; problem solving through } \\
\text { nontraditional } \\
\text { patterns of thinking. }\end{array}$ & $\begin{array}{l}\text { Shows exceptional inventiveness } \\
\text { in using everyday materials; is } \\
\text { keenly observant; has wild, } \\
\text { seemingly silly ideas; fluent, } \\
\text { flexible producer of ideas; highly } \\
\text { curious. }\end{array}$ \\
\hline $\begin{array}{l}\text { Humor } \\
\text { Conveys and picks up } \\
\text { on humor well. }\end{array}$ & $\begin{array}{l}\text { Ability to synthesize key ideas or } \\
\text { problems in complex situations in } \\
\text { a humorous way; exceptional } \\
\text { sense of timing in words or } \\
\text { gestures. }\end{array}$ & $\begin{array}{l}\text { Keen sense of humor that may be } \\
\text { gentle or hostile; large } \\
\text { accumulation of information } \\
\text { about emotions; capacity for } \\
\text { seeing unusual; uncommon } \\
\text { emotional depth; openness to } \\
\text { experiences; sensory awareness. }\end{array}$ \\
\hline $\begin{array}{l}\text { Intensity } \\
\text { Strength of reactions, } \\
\text { responses, behaviors. }\end{array}$ & $\begin{array}{l}\text { Very sensitive and extreme } \\
\text { responses to stimuli in five } \\
\text { areas: emotional, intellectual, } \\
\text { sensory, psychomotor, and } \\
\text { imagination. }\end{array}$ & $\begin{array}{l}\text { Intense desire for experiences in } \\
\text { the area(s) of overexcitability; } \\
\text { powerful emotions; seeks } \\
\text { intellectual stimulation; sensory } \\
\text { experiences induce strong } \\
\text { responses; constant or repetitive } \\
\text { movement or gesturing; intense } \\
\text { fantasy life; may need creative } \\
\text { area for intensity. }\end{array}$ \\
\hline $\begin{array}{l}\text { Sensitivity } \\
\text { Strong reactions to } \\
\text { emotional stimuli. }\end{array}$ & $\begin{array}{l}\text { Events and situations in the } \\
\text { affective and social domains } \\
\text { prompt a stronger response than } \\
\text { usual. }\end{array}$ & $\begin{array}{l}\text { Strong sense of sympathy; intense } \\
\text { sense of justice; empathy; moral } \\
\text { and ethical sensibilities; sense of } \\
\text { being "different" socially; } \\
\text { existential worrying; often overly } \\
\text { self-critical. }\end{array}$ \\
\hline
\end{tabular}

\section{Methodology}

This research uses a case study design involving a gifted child named as 'child $\mathrm{P}$ ' from Pusat GENIUS@pintar Negara, Malaysia. He is 13 years old and has passed the gifted identification tests named as UKM1, UKM2, and UKM3. This study has been conducted for 3 months from $12^{\text {th }}$ February 2019 until $12^{\text {th }}$ May 2019. Data were collected in three phases. Firstly, in-depth interviews were conducted with a gifted child and his parents to gather intense information about the child's behavior and emotional traits. Secondly, documents such as certificates, exam results and recognition letters granted to the gifted child were analysed. Thirdly, observations were conducted on the children in classroom and school events focusing on his behavior towards lesson and social events. Information and data from these various sources on child P's developmental history, personal characteristics and interests, learning behaviour, learning 
performance, and social relationships were analysed to construct a profile of his learning abilities and needs.

\section{Results}

Child $\mathrm{P}$ is achieving an extremely high level of cognitive and practical skills in many areas compared to his peers. He was able to talk and use simple sentences around the age of two years; read and do simple Mathematics at the age of 4 . He could also remember things easily that were taught only once when he was merely a toddler. According to his parents, there were some special characteristics shown by child $\mathrm{P}$ since he was 4 years old such as strong curiosity when something particularly caught his interest, extremely strong memory, exceedingly observant, strongly enjoyed being read to, initiated own learning, and preferred to play with older children. Child $\mathrm{P}$ has grabbed opportunities such as joining various competitions and performances at school and used it as platform to widen his knowledge, namely in music, mathematics and technology. During primary school, he has been awarded as Exemplary Student and Best Overall Student award, every single year. He loved to participate in competitions such as chess, robotics, taekwondo, science and mathematics with special interest in computers or ICT. This shows that child $\mathrm{P}$ is a versatile student by not only excel in academic but also in extracurricular field. He is a critical minded person with a perfectionist character, for instance when dealing with tasks given, he will do it analytically perfect and if he did not complete the task, he will never feel satisfied. His parents claimed that child $\mathrm{P}$ always thinks about any topic which he would argue on some points intensely, enjoys intellectual problemsolving activities, as well as is a detailed, tidy and organised person at home.

All of these traits are continued in his secondary school which offers him a lot of opportunities and more challenging. Child $\mathrm{P}$ has then succeeded to join a special secondary school known as National Gifted Centre after passing the UKM 1 and UKM 2 tests in 2018. Based on the test results, child $\mathrm{P}$ possessed a 17 years old mental age compared to his actual age of 11 years old. In this school, he keeps excellent track record both academic and extracurricular activities. He has become best student in four subjects which are Physics, Chemistry, Self- Development and French Language. Based on his current academic result on March 2019, he scored 2 A-, 8 A and $4 \mathrm{~A}+$ for all 14 subjects taken with CGP (Cumulative Grade Points) 3.76. Comparing to November 2019 result, he earned $1 \mathrm{~B}+, 1 \mathrm{~A}-, 4 \mathrm{~A}$, and $5 \mathrm{~A}+$ for 11 subjects taken with the same CGP 3.76. This has made his CGPA (Cumulative Grade Points Average) for the recent exam as 3.82 including non-academic subjects scored. Based on this excellent result, child $\mathrm{P}$ is passing the school excellency indicating at 3.67 which makes him eligible to receive a 'Director Award'. Although he has only enrolled in this school for $1 \frac{1 / 2}{2}$ year, he has shown extraordinary achievements. He has also won gold medals in World Scholar Cup 2018, Beaver Computational Thinking 2018, and Asean Science \& Math Olympiad 2018. This reflects on what his parents explained earlier that child $\mathrm{P}$ has mounting interest in Science, Math and Computer (ICT).

Based on the observation, child $\mathrm{P}$ showed more outstanding achievements. It is found that, child $\mathrm{P}$ became the first person who finished the quiz with full mark in completing music history task. In the music instrument class, he could play violin very well although he possessed no experience on playing it. The teacher just informed verbally on violin techniques and fingering at the beginning of the class. He took 30 minutes to fully play a music sheet entitled Twinkle-Twinkle with a perfect sound and stylish playing compared to other children. This obviously can be observed in the class when he could grip the violin bow correctly and play correct notes based on score sheet. While in Physics and Chemistry classes, his teachers agreed that child P showed a very strong characteristics during the lessons. Both teachers perceived 
same views, mentioning that child $\mathrm{P}$ copes well with repetitive work, completes task, grasps concepts quickly, effective leader, easy to make friends and strives to be best. Overall, child P is liked by teachers because of these attributes.

Child $\mathrm{P}$ has explained about himself thoroughly during the interview. Some answers were incidental to his parents and teachers' observations. He enjoyed watching informational video in the YouTube such as climate change. This issue has rattling captured his attention and made him very concern about the climate change. He continued that he has a lot of ideas to cater the problem, but it is rather difficult to express them due to the lack of power and ability. Additionally, school has helped him to express his creativity especially in the visual art and music class. This shows that his current school has catered and fullfilled his cognitive and practical needs in expressing his creativity. However, it seemed that being inventive is not his forte. He was not confident to say that he is an inventive person because he felt rather difficult to create and make something better. He liked to read fictional books and would focus on the book that captures his attention such as Harry Potter. He could finish the book in a short time. This is aligned to what his parents and teachers observed which child P has strong curiosity when something particularly caught his interest. He loved discussing and sharing ideas with close friends and parents. This is the evidence that he is not a lone ranger. He felt comfortable working with others and sharing ideas with them. In this school, he has a lot of platforms to share ideas be it formally (eg. in classroom and competitions joined) or informally (eg. hostel activities and leisure sports). However, he found that the school did not give total freedom to him because everything was done systematically in managing his routine. Nevertheless, he is coping and adapting it. It's challenging coping with the syllabus at school. He assumed that his friends are smart, and this has created a competitive surrounding for him. He was interested in arts and engineering courses but was not confident to further brief about his future. Overall, his explanation was more about creative works to fulfil his needs, releasing stress and to keep him happy. He also found drawing is very fascinating.

In addition, child $\mathrm{P}$ felt adults nowadays are causing harm to the environment. He was very concern about the environment, public transportation and green technology. He would love to see a cleaner energy, not depending on petroleum sources to make earth a better place. Now, he seemed confident to say that he wanted to be engineered to preserve the environment. He wished the school might implement programme in extracurricular activities to uphold the importance of the environment and spread the awareness of what is currently happening to our world today. To become a leader in the future is his ambition, with the preference of a CEO in technological companies such as Samsung, Apple and others. He also admitted that he is a quick learner. This is aligned with what his teachers observed which he could grasp concepts quickly. He also said that he is creative and all-rounder person but not in sports. This reflected on the observation during the Sports Day. It is approved when he did not have total interest in areas such as sports, he may become a passive person and may show his introvert character, clearly.

\section{Discussion}

Based on the evidences, I found that child P is a well catered person. I believe his parents and school have given strong support towards him to groom his giftedness. This has made child $\mathrm{P}$ to achieve high level of cognitive and practical skills in many areas compared to his peers who are in the same age. Child $\mathrm{P}$ is special child because he has a strong capacity especially in cognitive skills. He succeeded in achieving high scores in academics and could deliver ideas clearly and systematically. He also has talent in arts; visual arts and music. His sensitivity to make the earth as a better place is genuinely impressive. As a gifted person, he seemed to know 
his duty to serve people in the future. Although he did not perform in sports, it was not a problem for him as he possessed high skill in computation. He also possessed a math and science intellect. Based on the material from the National Research Center on the Gifted and Talented by Mary Ruth Coleman, Ph.D., University of North Carolina, child P has shown 12 traits of giftedness with the strong qualities on interests, motivation, memory, inquiry, insight, creativity and sensitivity. These also are aligned with the Characteristic of Giftedness developed by Dr Linda Silverman. Based on Revised Profiles of the Gifted \& Talented table by Betts and Neihart (1988), most of child P's characters fall under "The Successful" type. This is a good indication for him to become an outstanding and potentially excellent gifted individual in the future. Therefore, steps to nurture and widen his giftedness should be increased and well monitored.

The following suggestions may help child $\mathrm{P}$ to sharpen his giftedness:

i. His classroom programme should be planned to ensure that acceleration is always available to him.

ii. The integration of arts elements in each lesson in the class should be inserted as he attracted to arts.

iii. Chances to learn independently to foster creativity.

iv. School should organize more events about current issues such as climate change, terrorism, extremism and so forth.

v. School should conduct activities that push out of his comfort zone.

vi. child P's parents may investigate the possibility of joining school summer camp at the end of the year to enrich child P's skills.

\section{Conclusion}

To conclude, gifted children have their own uniqueness. Their abilities and skills have been shown from the beginning, and this can be recognized by their own parents. Gifted and talented children in fact have high potential in various fields based on their individual interests. Their abilities are different compared to children their age and some are able to overcome the intelligence or abilities possessed by older people. Besides, teachers' role is very important to prepare appropriate education needs for gifted children. Identification process, differentiated learning, and contents are things that should be implemented by teachers at school as suggested by Parke (1989). Giftedness is developed from the intellectual aspect as well as the moral and spiritual domains. It is not a surprise for us that there are gifted children who fail in life because of poverty or lack of concern in sharpening giftedness among the children.

\section{References}

Betts, G., \& Neihart, M. (1988). Profiles of the gifted and talented. Gifted Child Quarterly, $32(2), 248-253$.

Bainbridge, C. (2019, April 22). What Are the Traits and Characteristics That Make Gifted Kids Unique? Retrieved October 6, 2019, from https://www.verywellfamily.com/characteristics-of-gifted-children-1449114.

Da Costa, M. P., \& Lubart, T. I. (2016). Gifted and talented children: Heterogeneity and individual differences. Anales de Psicología/Annals of Psychology, 32(3), 662-671.

Diezmann, C. M. (2002). Capitalising on the zeitgeist for mathematically gifted students. Australasian Journal of Gifted Education, 11(2), 5-10.

Gagne, F.(2015) Academic talent development programs: A best practices model. Asia Pasific Education Review 16:281-295

Gardner, H. E. (2000). Intelligence reframed: Multiple intelligences for the 21 st century. Hachette UK. 
Goleman, D. (2000). Leadership that gets results. Harvard business review, 78(2), 4-17.

Kwaśniewska, J. M., Gralewski, J., Witkowska, E. M., Kostrzewska, M., \& Lebuda, I. (2018). Mothers' personality traits and the climate for creativity they build with their children. Thinking Skills and Creativity, 27, 13-24.

Mayer, J. D. (2010). Salovey. P.(1997). What is emotional intelligence. Emotional development and emotional intelligence: Educational implications, 3-31.

Md Jais B. I. Rorlinda B. Y.., \& Loo F. C. (2018). Proper Musical Activities During Music Instructional Process for Gifted and Talented children in Malaysia. Malaysian Journal of Social Sciences and Humanities (MJSSH), 3(5), 30-40.

Noriah M.I.(2019). Memupuk Kepintaran Pelajar Pintar Dan Berbakat: Peranan dan Cabaran Kaunselor. Penerbit UKM Press. Bangi.

Noriah M.I. (2005). Kecedasan emosi: Kompetensi utama di kalangan kaunselor-satu kemungkinan. Prosiding Seminar Kaunseling Kementerian Pelajaran Malaysia, Langkawi.

Noriah M.I. \& Abu Yazid, A.B.(2014) Counseling services for Malaysian gifted children: An In initial study. Journal for Advancement of Counselling. 36(4): 372-383.

Parke, B. N. (1989). Educating the Gifted and Talented: An Agenda for the Future. Educational leadership, 46(6), 4-5.

Renzulli, J. S. (2002). Emerging conceptions of giftedness: Building a bridge to the new century. Exceptionality, 10(2), 67-75.

Terman, L. M., \& Merrill, M. A. (1960). Stanford-Binet Intelligence Scale: Manual for the third revision, Form LM.

Worrell, F. C., Subotnik, R. F., Olszewski-Kubilius, P., \& Dixson, D. D. (2019). Gifted children. Annual review of psychology, 70, 551-576.

Zohar, D. Marshall (2012). Spiritual Intelligence: The Ultimate Intelligence. London: Bloomsbarry. 